\title{
When a Pesticide Doesn't Work ${ }^{1}$
}

\section{Frederick M. Fishel $^{2}$}

\section{Introduction}

Pesticides are valuable additions to the box of tools available to pest managers. However, they should be considered as one part of the total integrated pest management (IPM) plan rather than the only solution. Pesticide failure can occur for a variety of reasons:

- Improper pest identification (incorrect pesticide selection)

- Incorrect pesticide dosage

- Improper application timing

- Pesticide does not reach target pest

- Unfavorable environmental conditions

- State of poor pesticide condition

- Pesticide resistance

\section{Improper Pest Identification - Incorrect Pesticide Selection}

Accurate pest identification should be the first step. Being able to accurately identify pests requires patience and practice. Subtle differences among pest species may often lead to a false identification. For example, control methods vary for different species of grassy weeds. Although they may have common features, such as parallel veins and round stems, crabgrass and bermudagrass control tactics are not always the same. Crabgrass is an annual, while bermudagrass is a tougher-to-control perennial with vegetative rhizomes and stolons. Although some postemergence herbicides may control both species, preemergence herbicides will only reliably control crabgrass.

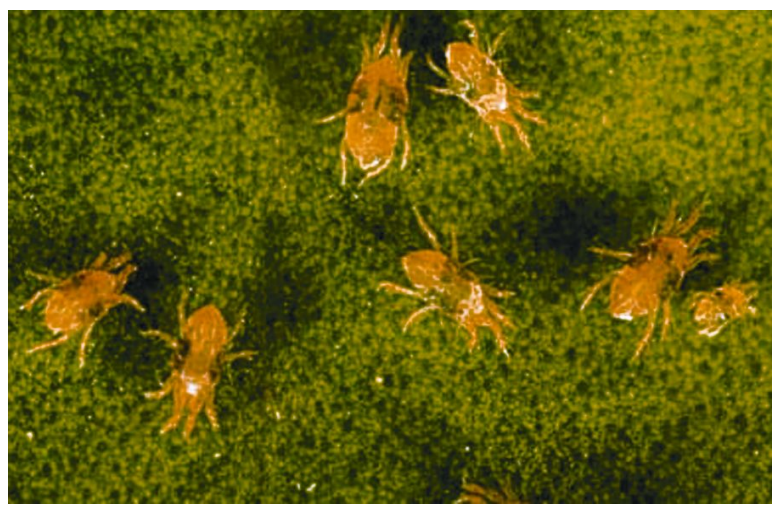

Figure 1. Mites are extremely small and difficult to distinguish among species. Credits: J.L. Castner UF/IFAS

Likewise, different species of mites (Figure 1) can be difficult to distinguish from one another

1. This document is PI-163, one of a series of the Agronomy Department, Florida Cooperative Extension Service, Institute of Food and Agricultural Sciences, University of Florida. Original publication date May 2008. isit the EDIS Web Site at http://edis.ifas.ufl.edu.

2. Frederick M. Fishel, Associate Professor, Agronomy Department, and Director, Pesticide Information Office; Florida Cooperative Extension Service, Institute of Food and Agricultural Sciences, University of Florida, Gainesville, FL 32611.

Use pesticides safely. Read and follow directions on the manufacturer's label. 
because of their extremely small bodies. However, the pesticides selected to control different mite species can vary. An example would be pesticide selection for the control of spider mites and rust mites in citrus.

Regardless of the pest class, making an accurate identification is critical. University of Florida's Institute of Food and Agricultural Sciences offers a variety of services to help determine the cause of plant problems and can provide pest identification through the Florida Plant Disease Clinic Network (http://plantpath.ifas.ufl.edu/pdc/Default.htm).

\section{Incorrect Pesticide Dosage}

Several reasons may account for this problem. Application equipment should be properly calibrated to deliver a known volume. Underdosing can be expensive because retreatment may be necessary. On the other hand, overdosing is a violation of the product's label wording. Keep in mind that the rate listed on a product label as controlling one specific pest, will not necessarily be the amount needed to control other species (Figure 2).

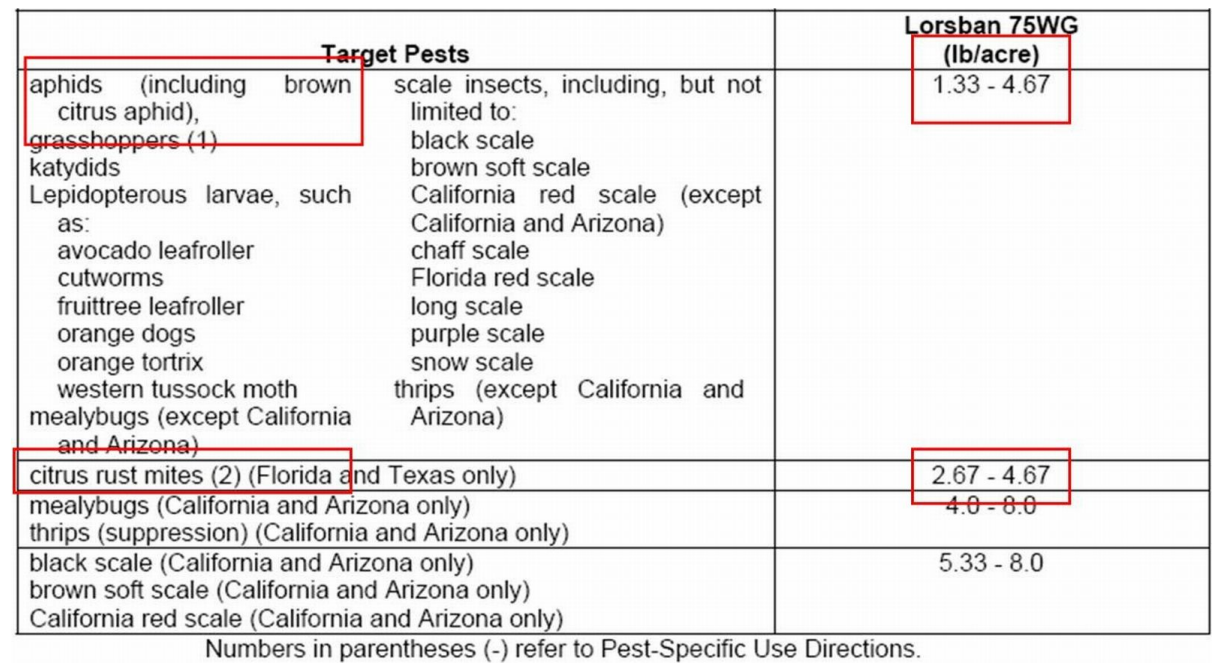

Figure 2. Product rates often vary by pest species. Credits: CDMS

\section{Improper Application Timing}

Apply the pesticide to the life stage of the pest that is most susceptible to the effects of the pesticide. Generally, herbicides are most effective on small, early stages of weed growth. Many insecticides are effective on insect larvae or nymphs, but not on adults. Some pesticide labels will list their rates based upon growth stage or size (Figure 3).
Another potential problem involving timing is an application that takes place after the infiltration or departure of a pest. An application of a protectant fungicide will provide little, or no, control of a plant pathogen that has already invaded its host plant. Many labels will instruct that applications should begin prior to the onset of infection.

\begin{tabular}{|c|c|c|c|c|c|c|}
\hline \multirow{3}{*}{$\begin{array}{l}\text { WEEDS CONTROLLED (includes } \\
\text { ALS and triazine resistant biotypes) }\end{array}$} & \multirow{2}{*}{\multicolumn{2}{|c|}{1 pint per acre }} & \multicolumn{3}{|c|}{ DASAURAIVRATES PER ACRE } & \multirow[b]{2}{*}{2 pints per acre } \\
\hline & & & \multicolumn{2}{|c|}{1.5 pints per acre } & 2 pint & \\
\hline & Leaf Stage & $\begin{array}{c}\text { Maximum } \\
\text { Height }\end{array}$ & Leaf Stage & $\begin{array}{l}\text { MraxImum } \\
\text { Height }\end{array}$ & Leaf Stage & $\begin{array}{c}\text { Maximum } \\
\text { Height }\end{array}$ \\
\hline Anoda, Spurred & 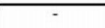 & - & Up to 6 & $3^{\prime \prime}$ & $6-8$ & $4^{n}$ \\
\hline Balloonvine & - & - & $2-4$ & $2^{\prime \prime}$ & 4-6 & $3^{n}$ \\
\hline Beggarticks & - & - & Up to 6 & $6^{\prime \prime}$ & $6-8$ & $8^{\prime \prime}$ \\
\hline Bindweed (Field, Hedge) 6 & - & - & - & - & - & $10 "$ \\
\hline Buckwheat, Wild & 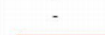 & - & Up to 4 & $3^{n}$ & $4-6$ & $5^{\prime \prime}$ \\
\hline Canada Thistle? & & & & & & toutstage \\
\hline Cocklebur 2,9 & $2-4$ & $4^{\prime \prime}$ & $2-6$ & 6" & $6-10$ & $10 "$ \\
\hline $\begin{array}{l}\text { Croton, Tropic } \\
\text { Dayflower }\end{array}$ & - & - & Up to 6 & $4^{\prime \prime}$ & $6-10$ & $8^{n}$ \\
\hline Devilsclaws & - & - & - & 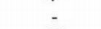 & Up to 6 & $3^{\prime \prime}$ \\
\hline Eclipta & - & - & Up to 6 & $2^{n}$ & Up to 6 & $2^{*}$ \\
\hline Galinsogas & - & - & - & - & Cotyledon to 6 & $2^{n}$ \\
\hline Groundsel, Common & - & 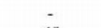 & - & - & - & $3^{\prime \prime}$ \\
\hline Jimsonweed & Up to 4 & $4^{\prime \prime}$ & Up to 6 & $6^{\prime \prime}$ & $6-10$ & $10^{\prime \prime}$ \\
\hline Ladysthumb & Up to 4 & 4" & Up to 6 & $6^{\prime \prime}$ & $6-10$ & $10 "$ \\
\hline Lambsquarters, Common3,4 & Up to 4 & $1 "$ & Up to 6 & $1.5^{\prime \prime}$ & Up to 6 & $2^{\prime \prime}$ \\
\hline Marshelder & - & - & Up to 4 & $2^{n}$ & Up to 8 & $4^{\prime \prime}$ \\
\hline Mayweed/dogfennel & - & - & - & $2^{\prime \prime}$ & - & $3^{\prime \prime}$ \\
\hline $\begin{array}{l}\text { Morningglory } 10 \text { (smallflower, } \\
\text { cypressvine only) }\end{array}$ & . & - & 4 & $4^{\prime \prime}$ & 4 & $4^{\prime \prime}$ \\
\hline Morningglory 10 & 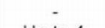 & - & 4 & $4^{\prime \prime}$ & 6 & $6^{\prime \prime}$ \\
\hline Mustard, Wild & Up to 4 & $2^{a}$ & Up to 6 & $4^{\prime \prime}$ & $6-10$ & $8^{\prime \prime}$ \\
\hline Niqhtshade, hairy 12 & & 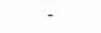 & - & - & $2-6$ & $4^{\prime \prime}$ \\
\hline
\end{tabular}

Figure 3. Product rates may vary according to pest growth stage or size. Credits: CDMS 


\section{Pesticide Does Not Reach Target Pest}

Sometimes pesticide applications aren't effective because the pest is in a difficult-to-reach location that is difficult for the pesticide to reach. Many insects are located on the underside of leaves, under bark or soil, or within stems and fruits (Figure 4). When insects are on leaf undersides, applicator sprays must be directed at those areas to have an effect.

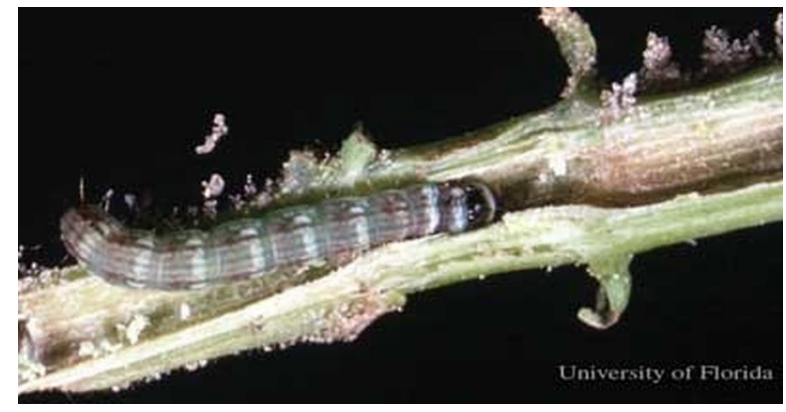

Figure 4. Pests like the lesser cornstalk borer can be located in difficult-to-reach places. Credits: J.L. Castner, UF/IFAS

After application, some pesticides must be watered, by either rainfall or irrigation, into the soil zone where underground insects are feeding. Read the label for maximum product efficacy (Figure 5). control is not maximized. Windy conditions can cause pesticides to drift from their intended sites and can also result in damage to desirable plants. (Figure 6). Injuries of this sort are subject to legal penalties

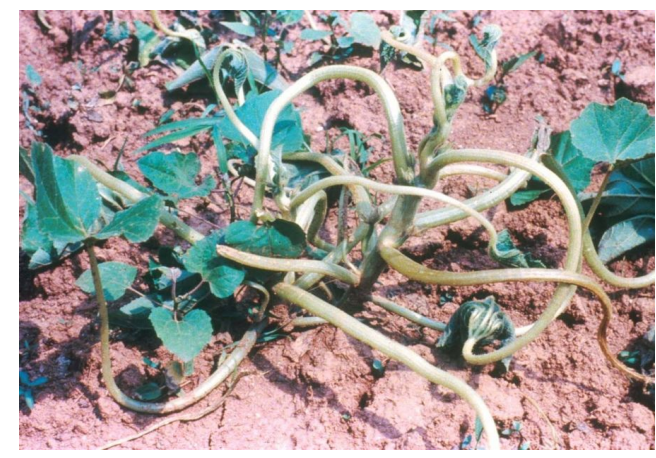

Figure 6. Organo-auxin herbicide injury to squash. Credits: UF/IFAS Pesticide Information Office

\section{State of Poor Pesticide Condition}

Under some conditions, some pesticides can change into a form that is not effective. The age of the pesticide, moisture, and temperature extremes are the primary factors responsible for chemical reactions which alter the formulation's active ingredient, rendering them ineffective. Moisture is generally a problem when dry products are stored in bags or containers that have not been adequately sealed. Statements on the product's label often instruct the

\section{TURFGRASS}

Apply the recommended rates using pressure-type equipment in sufficient spray volume for thorough coverage and thatch penetration.

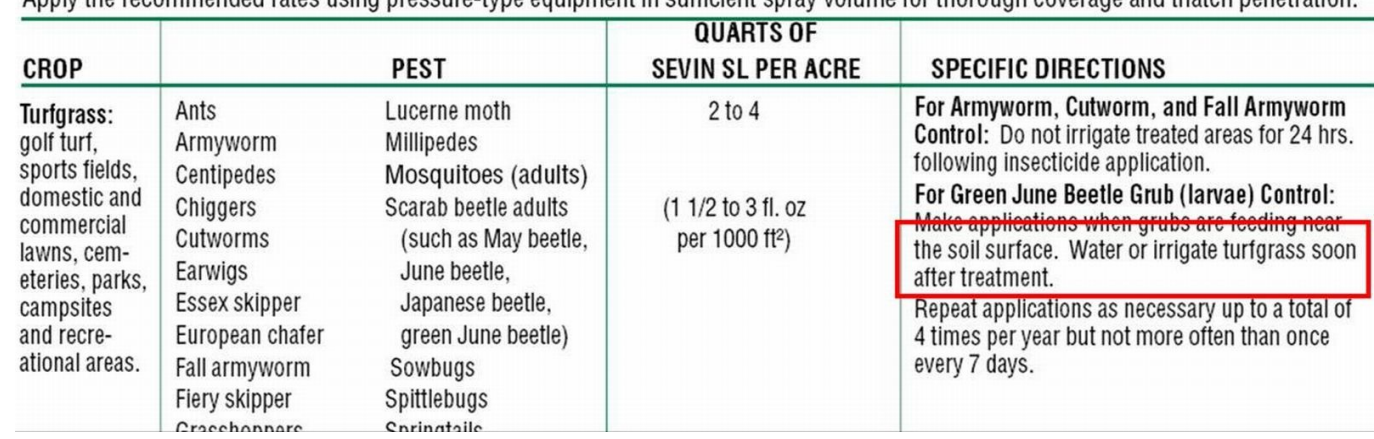

Figure 5. Some labels recommend watering to move a product to the pest's location. Credits: CDMS

\section{Unfavorable Environmental Conditions}

Aside from the examples above, most pesticides should not be applied just prior to or during rainfall. Rain washes pesticides off foliage before they have time to take effect. High temperatures, lack of moisture, and both acid and alkaline soil $\mathrm{pH}$ produce thicker cuticle formation on the surface of weeds. Thick cuticles prevent herbicide uptake, thus weed user not to store the product in extreme heat (Figure 7 on page 4). Heat may also cause volatilization of some pesticides if their containers are not adequately sealed. Such statements are found in the "Storage and Disposal" section of the product labels.

\section{Pesticide Resistance}

Pesticide resistance does not occur as often as some applicators may think. Although there are documented cases of more than 500 arthropod, and 


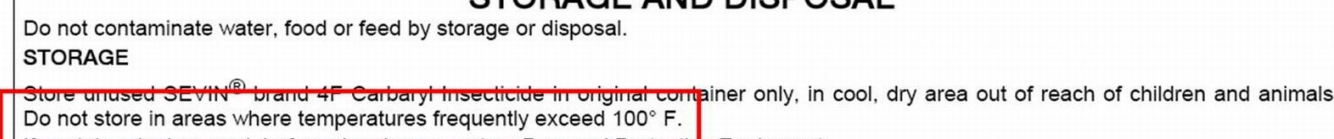

Figure 7. Storage statement regarding high temperature. Credits: CDMS

200 fungi and weed species, this is not the most common reason pesticides fail. Resistance often develops in pest populations that have been repeatedly treated with a single pesticide. Development of resistance in pest populations may sometimes be averted or delayed by avoiding the use of persistent pesticides, reducing the number of treatments and alternating pesticide modes of action.

\section{Summary}

There are many factors responsible for a pesticide's failure to controlling a pest. Although there are additional reasons, most often some type of human error is involved. Some failures can be avoided by simply following the product's label directions. Use common sense; read and follow all labels.

\section{Additional Information and References}

Ferrell, J.A., G.E. MacDonald, B.A. Sellers, and C.R. Rainbolt. 2006. Calibration of herbicide applicators. UF/IFAS EDIS Extension Document SS-AGR-102. http://edis.ifas.ufl.edu/WG013. (accessed February, 2008).

Fishel, F.M. 2006. Storage limitation statements: temperature - fungicides. UF/IFAS EDIS Extension Document PI-122. http://edis.ifas.ufl.edu/PI159. (accessed February, 2008).

Fishel, F.M. 2006. Storage limitation statements: temperature - herbicides. UF/IFAS EDIS Extension Document PI-123. http://edis.ifas.ufl.edu/PI160. (accessed February, 2008).
FRAC: http://www.frac.info/frac/index.htm. (accessed February, 2008).

HRAC: http://www.hracglobal.com/. (accessed February, 2008).

IRAC: http://www.irac-online.org/groups/guide. (accessed February, 2008).

C.R. Rainbolt, B.A. Sellers, Ferrell, J.A., and G.E. MacDonald. 2006. Calibration of herbicide applicators. UF/IFAS EDIS Extension Document SS-AGR-243. http://edis.ifas.ufl.edu/AG239. (accessed February, 2008).

Rogers, M.E., L.W. Timmer, and C.W. McCoy. 2007. 2008 Citrus pest management guide: pesticide resistance and resistance management. UF/IFAS EDIS Extension Document ENY-624. http://edis.ifas.ufl.edu/CG026. (accessed February, 2008).

Stiles, C.M., M.T. Momol, P.D. Roberts, R. McMillan, R.E. Cullen, and G.W. Simone. 2002. Florida extension plant disease clinic network. UF/IFAS EDIS Extension Document RF-SR007. http://edis.ifas.ufl.edu/SR007. (accessed February, 2008). 